\title{
PERILAKU PETANI POLA SWADAYA DAN PLASMA TERHADAP PRAKTIK PRODUKSI KELAPA SAWIT BERKELANJUTAN DI KAMPAR, RIAU
}

\author{
Fitri Yutika ${ }^{1}$, Eko Ruddy Cahyadi ${ }^{2}$, Heti Mulyati ${ }^{3}$ \\ 1) Mahasiswa Program Magister Ilmu Manajemen, Sekolah Pascasarjana, Institut Pertanian Bogor \\ 2) Departemen Manajemen, Fakultas Ekonomi dan Manajemen, Institut Pertanian Bogor \\ 3) Departemen Manajemen, Fakultas Ekonomi dan Manajemen, Institut Pertanian Bogor \\ email: ${ }^{1) y u t i k a \_s i h o @ a p p s . i p b . a c . i d ~}$ \\ (Diterima 18 Juli 2019/Disetujui 15 Agustus 2019)
}

\begin{abstract}
Indonesian palm oil plantation industry is confronted with sustainability issues that potentially restrict trade access in theglobal market. Smallholders are actors who have an important role in palm oil plantation sustainable development. Theory of Planned Behavior (TPB) and past behavior are used as the theoretical basis to see the influence of attitude toward sustainability, subjective norm, perceived behavioral control and past behavior toward smallholders' intention to implement sustainable palm oil production practices. This study aims to analyze differences in smallholders' intention to implement sustainable palm oil production practices between independent farmers and plasma farmers. The study sample consisted of 121 independent farmers and 121 plasma farmers wich is spread across Kampar Regency. Data collection was done by distributing questionnaires and analyzed using Structural Equation Modeling (SEM) with Partial Least Square (PLS) program. The result of this study indicates that attitude toward sustainability, subjective norm, perceived behavioral control and past behavior have a positive and significant effect on plasma farmers' intention to implement sustainable palm oil production practices, whereas subjective norm has no effect on the independent farmers' intention to implement sustainable palm oil production practices.
\end{abstract}

Keywords: independent farmer, plasma farmer, smallholder's intention, sustainable palm oil, a theory of planned behavior

\begin{abstract}
ABSTRAK
Industri perkebunan kelapa sawit di Indonesia dihadapkan dengan berbagai isu keberlanjutan yang dapat menghambat akses perdagangan di pasar global. Petani kelapa sawit merupakan aktor yang memiliki peranan penting dalam pembangunan perkebunan kelapa sawit berkelanjutan. Theory of Planned Behavior (TPB) dan perilaku masa lalu digunakan sebagai landasan teori untuk melihat pengaruh sikap terhadap keberlanjutan, norma subjektif, persepsi pengendalian perilaku dan perilaku masa lalu terhadap niat petani swadaya dan petani plasma untuk menerapkan praktik-praktik produksi kelapa sawit berkelanjutan. Sampel penelitian terdiri atas 121 orang petani swadaya dan 121 orang petani plasma yang tersebar di Kabupaten Kampar. Pengumpulan data dilakukan dengan penyebaran kuesioner dan dianalisis menggunakan Structural Equation Modeling (SEM) dengan program Partial Least Square (PLS). Hasil penelitian ini menunjukkan bahwa sikap terhadap keberlanjutan, norma subjektif, persepsi kontrol perilaku dan perilaku masa lalu berpengaruh signifikan terhadap niat petani plasma untuk menerapkan praktik-praktik produksi kelapa sawit berkelanjutan. Sedangkan pada petani swadaya, variabel norma subjektif tidak memiliki pengaruh terhadap niat petani menerapkan praktik-praktik produksi kelapa sawit berkelanjutan.
\end{abstract}

Kata kunci: petani plasma, petani swadaya, kelapa sawit berkelanjutan, perilaku petani, teori perilaku terencana 


\section{PENDAHULUAN}

Perkebunan kelapa sawit di Indonesia menurut status pengusahaannya diusahakan oleh perkebunan rakyat (smallholders) sebanyak 42,3 persen. Berdasarkan data Direktorat Jenderal Perkebunan (DITJENBUN), perkebunan rakyat mengalami peningkatan luas areal perkebunan setiap tahunnya (DITJENBUN 2017). Luas areal perkebunan rakyat akan terus meningkat menjadi pemilik pangsa kepengusahaan kelapa sawit terbesar di Indonesia. Hal ini dikarenakan terbatasnya lahan yang relatif luas di Indonesia, sehingga membatasi perusahaan besar untuk memperluas areal lahan (GAPKI 2017). Perkebunan rakyat diusahakan oleh petani pola plasma dan petani pola swadaya. Perusahaan inti membina dan mengembangkan perkebunan plasma penyediaan sarana produksi, pemberian bimbingan teknis manajemen usaha, penguasaan dan peningkatan teknologi yang diperlukan bagi peningkatan efisiensi dan produktifitas usaha (UU nomor 9 tahun 1995). Sedangkan petani swadaya merupakan petani yang dengan inisiatif dan biaya sendiri membuka dan mengelola lahan, tidak terkait dengan perusahaan tertentu (Andoko et al. 2013). Petani swadaya murni sama sekali belum memiliki kelembagaan KUD dan kelompok tani, yang disebabkan oleh lemahnya pembinaan oleh instansi, akibat tidak terdatanya pekebun kelapa sawit murni (Hadi et al. 2009).

Petani rakyat sebagai pelaku rantai pasok hulu memiliki peranan penting dalam menciptakan sistem rantai pasok yang terintegrasi dalam mengatasi isu berkelanjutan dan meningkatkan produktivitas. Dewasa ini, industri kelapa sawit Indonesia dihadapkan dengan isu keberlanjutan yang menjadi tantangan bagi seluruh pelaku rantai pasok, khususnya petani rakyat sebagai produsen. Menurut Palm Oil Agribusiness Strategic Policy Institute (PASPI), sejumlah Lembaga Swadaya Masyarakat (LSM) anti sawit melakukan kampanye negatif terhadap industri minyak sawit Indonesia. Kampanye tersebut mempengaruhi opini semua rantai pasok mulai dari konsumen, produsen, industri dan kelembagaan pendukung, hingga pemerintah (PASPI 2016). Isu keberlanjutan ini dapat menghambat akses pasar komoditas kelapa sawit di pasar internasional.

Sertifikasi RSPO (Roundtable Sustainable Palm Oil) dan ISPO (Indonesian Sustainable Palm Oil) merupakan standar dan parameter global berkelanjutan untuk produk-produk yang dihasilkan dari kelapa sawit. RSPO dan ISPO memiliki Principles $\mathcal{E}$ Criteria (P\&C) yang berfokus pada hukum, ekonomi, lingkungan, kebutuhan sosial untuk produksi kelapa sawit berkelanjutan (Aikanathan et al. 2011). Di dalam P\&C RSPO dan ISPO terdapat teknik budidaya dan pengelolaan kelapa sawit yang baik (Good Agriculture Practices/GAP), yang dapat mendukung pembangunan kelapa sawit berkelanjutan secara ekonomi, sosial dan lingkungan. Pembukaan lahan tanpa bakar, menggunakan pupuk organik, pengendalian organisme pengganggu tanaman (OPT) secara organik, menggunakan bibit bersertifikat, mengikuti kelompok tani, dan menggunakan lahan bebas konflik merupakan bagian dari praktik-praktik keberlanjutan pada GAP.

Keputusan petani dalam mengimplementasikan GAP didasari oleh motif-motif dan pertimbangan-pertimbangan kompleks, yang bukan hanya berkaitan dengan aspek ekonomi melainkan lebih bersifat psikologis (Hansson et al. 2013). Ajzen mengemukakan Theory of Planned Behavior (TPB) yang menjelaskan tindakan manusia dibimbing oleh 3 macam faktor, yaitu (1) keyakinan (belief) tentang hasil perilaku dan evaluasi terhadap hasil perilaku (behavior belief), (2) keyakinan tentang harapan normatif dari orang lain dan motivasi untuk menuruti dari adanya harapan tersebut (normative belief), dan (3) keyakinan tentang hadirnya faktor yang memfasilitasi atau menghambat perilaku, 
serta persepsi adanya power pada faktor tersebut (control belief) (Ajzen 2005).

Niat petani terhadap keberlanjutan dapat diprediksi dengan menggunakan TPB karena kemampuannya dalam menangani perilaku kompleks yang menggambarkan mekanisme yang membuat orang mendukung praktik-praktik berkelanjutan (Yazdanpanah et al. 2014, Menozzi et al. 2015, Terano et al. 2015, Zeweld et al. 2017, dan Wiratmadja 2017). Selain itu, pada saat seseorang tidak mampu untuk mengakses sikap, maka perilaku masa lalu merupakan prediktor untuk perilaku selanjutnya Dharmmesta (2000). Perilaku masa lalu dapat digunakan sebagai prediktor untuk mempengaruhi niat berperilaku individu, selain itu juga dapat melemahkan niat berperilaku (Hagger et al. 2002). Penelitian ini bertujuan untuk menganalisis perbedaan pengaruh sikap, norma subjektif persepsi pengendalian perilaku dan perilaku masa lalu terhadap niat petani kelapa sawit pola swadaya dan pola plasma dalam melakukan praktik-praktik produksi berkelanjutan di kabupaten Kampar.

\section{METODE}

\section{LOKASI DAN WAKTU PENELITIAN}

Penelitian ini dilakukan di Kabupaten Kampar, Riau. Pemilihan lokasi ini dilakukan dengan pertimbangan bahwa kabupaten Kampar merupakan daerah sentral penghasil kelapa sawit yang didominasi oleh perkebunan rakyat, dengan jumlah tenaga kerja petani terbesar dan tingkat produktivitas terendah di Provinsi Riau (Tabel 1). Penelitian ini dilakukan pada bulan Januari sampai Mei 2019.

Tabel 1. Luas area dan produksi kelapa sawit perkebunan rakyat Provinsi Riau tahun 2015

\begin{tabular}{|l|r|r|r|r|}
\hline \multicolumn{1}{|c|}{ Provinsi Riau } & $\begin{array}{c}\text { Luas kebun } \\
\text { TM (ha) }\end{array}$ & Produksi (ton) & $\begin{array}{c}\text { Produktivitas } \\
\text { (ton/ha) }\end{array}$ & Petani (KK) \\
\hline Kabupaten Kampar & 179.991 & 368.247 & 2.05 & 85,405 \\
\hline Kabupaten Rokan Hulu & 163.147 & 647.501 & 3.97 & 69,225 \\
\hline Kabupaten Rokan Hilir & 155.447 & 509.030 & 3.27 & 60,953 \\
\hline Kabupaten Siak & 186.239 & 642.270 & 3.45 & 64,326 \\
\hline Kabupaten Pelalawan & 115.604 & 452.530 & 3.91 & 40,165 \\
\hline Kabupaten Indragiri Hilir & 73.841 & 198.322 & 3.68 & 31,209 \\
\hline Kabupaten Kuantan & 61.131 & 165.931 & 2.71 & 42,303 \\
\hline Kabupaten Bengkalis & 104.627 & 298.976 & 2.85 & 37,653 \\
\hline Kabupaten Dumai & 24.581 & 80.388 & 3.27 & 10,092 \\
\hline Kota Pekanbaru & 773 & 2.855 & 3.69 & 704 \\
\hline
\end{tabular}

Sumber : DITJENBUN (2017); TM: Tanaman Menghasilkan

\section{SAMPEL PENELITIAN}

Populasi dalam penelitian ini adalah petani kelapa sawit pola swadaya dan pola plasma di perkebunan rakyat Kabupaten Kampar. Jumlah minimal sampel ditentukan berdasarkan rumus slovin dengan tingkat kepercayaan 95 persen. Berdasarkan perhitungan jumlah minimal yang didapat, maka ditentukan proporsi sampel berdasarkan persentase jumlah petani dari masing-masing kecamatan dikali jumlah minimal sampel. Kemudian jumlah sampel tiap kecamatan dibagi 2 untuk menentukan jumlah sampel petani swadaya dan petani plasma. Sehingga total seluruh sampel adalah 242 orang. Jumlah sampel yang digunakan dalam penelitian ini adalah 121 orang petani swadaya dan 121 orang petani plasma. Teknik penentuan sampel dilakukan secara convenience, yaitu teknik pengambilan sampel berdasarkan kriteria yang telah dirumuskan peneliti.

\section{DATA PENELITIAN}

Data yang digunakan dalam penelitian ini adalah data primer dan data sekunder. Data primer merupakan data yang diperoleh secara langsung melalui 
wawancara dengan teknik kuesioner terhadap sampel/responden. Sedangkan data sekunder merupakan data pendukung yang diperoleh dari studi kepustakaan, data statistik dan penelitian terdahulu yang relevan dengan penelitian.

\section{VARIABEL PENELITIAN}

Variabel dalam penelitian ini menggunakan landasan Theory of Planned Behavior (TPB) dan perilaku masa lalu. Variabel sikap terhadap keberlanjutan dibentuk oleh komponen keyakinan perilaku dan evaluasi konsekuensi, variabel norma subjektif dibentuk oleh komponen keyakinan normatif dan motivasi memetuhi, variabel persepsi pengendalian perilaku dibentuk oleh komponen keyakinan pengendalian dan kekuatan faktor pengendali, variabel perilaku masa lalu dan variabel niat menerapkan praktik-praktik produksi kelapa sawit berkelanjutan (GAP). Variabel-variabel tersebut diukur menggunakan kuesioner dengan skala pengukuran 1 sampai 7 .

\section{ANALISIS DATA}

Pengolahan data dilakukan dengan menggunakan program softwere Microsoft Office Excel 2013 dan Smart Partial Least Squre (PLS). Teknik analisis data yang digunakan dalam penelitian ini yaitu analisis deskriptif statistika dan Structural Equation Modeling (SEM). Hubungan antara prediktor TPB dan perilaku masa lalu dengan niat untuk menerapkan praktik-praktik keberlanjutan akan dibahas, dibenarkan, dan diuji secara empiris menggunakan teknik pemodelan persamaan struktural (SEM) (Wiratmadja 2017 dan Terano et al. 2015).

\section{HASIL DAN PEMBAHASAN}

\section{GAMBARAN UMUM SAMPEL PENELITIAN}

Responden dalam penelitian ini terdiri atas dua jenis pola tani yaitu petani plasma sebanyak 121 orang $(50 \%)$ dan petani swadaya sebanyak 121 orang (50\%). Petani pola plasma merupakan program kerja sama antara petani dengan perusahaan swasta atau pemerintah sebagai inti, sedangkan petani pola swadaya adalah petani yang mengelola kebun kelapa sawitnya secara mandiri. Perusahaan inti membina dan mengembangkan perkebunan plasma, penyediaan sarana produksi, pemberian bimbingan teknis manajemen usaha yang diperlukan bagi peningkatan efisiensi dan produktifitas kebun. Hal ini menyebabkan petani plasma hanya bergantung pada program pengelolaan dari KUD dan tidak mengambil keputusan sendiri untuk menambah perlakuan ekstra seperti pupuk organik dan POPT secara organik. Sementara petani swadaya memiliki kewenangan sendiri untuk menentukan dan mengambil keputusan pada pengelolaan usaha taninya.

\section{KARAKTERISTIK RESPONDEN}

Tabel 2 menunjukkan tidak terdapat perbedaan nyata $(\mathrm{p}>0.05)$ usia, pendidikan dan sumber penghasilan antara responden petani swadaya dan petani plasma. Usia merupakan salah satu faktor yang mempengaruhi produktivitas bekerja. Usia produktif secara ekonomi dibagi menjadi 3 kelompok, yaitu kelompok usia belum produktif (0-14 tahun), kelompok usia produktif (15-65 tahun), dan kelompok usia tidak lagi produktif ( $>65$ tahun). Responden berada pada usia produktif, dengan rata-rata usia petani swadaya 49.66 tahun dan petani plasma 47.71 tahun. Artinya responden cukup potensial untuk melakukan kegiatan usaha taninya secara berkelanjutan. Responden memiliki tingkat pendidikan yang rendah, dengan rata-rata lama pendidikan petani swadaya 8.23 tahun dan petani plasma 8.47 tahun. Hal ini menunjukkan bahwa responden tidak memiliki ilmu dan wawasan mengenai pertanian berkelanjutan dari pendidikan formal. Sebagian besar sumber penghasilan responden adalah dari usaha tani kelapa sawit. Rata-rata penghasilan petani swadaya dari kelapa sawit adalah 85 persen dan petani plasma 82 persen. baik pola swadaya $(59 \%)$ maupun pola plasma $(46 \%)$. Sumber 
penghasilan tambahan bagi petani swadaya dan petani plasma adalah usaha dagang warung atau toko, nelayan, karyawan perusahaan, serta buruh harian lepas.

Tabel 2 juga menunjukkan terdapat perbedaan nyata $(\mathrm{p}<0.05)$ luas lahan, hasil panen dan usia tanaman kelapa sawit antara responden petani swadaya dan petani plasma. Petani pola swadaya memiliki bidang lahan lebih luas dibandingkan dengan pola plasma. Rata-rata luas lahan kelapa sawit petani swadaya adalah 4.95 hektar, sedangkan rata-rata luas lahan kelapa sawit petani plasma adalah 2.98 hektar. Sirait et al. (2013) menyatakan bahwa minimum skala usaha untuk perkebunan kelapa sawit rakyat adalah 2 sampai 4 hektar. Berarti, petani responden memiliki luas kebun yang cukup untuk memenuhi kebutuhan input produksi dan kebutuhan hidup petani. Ratarata hasil panen dari kebun petani swadaya adalah 1.54 ton/ha, sedangkan rata-rata hasil panen kebun petani plasma adalah 1.78 ton/ha. Hal ini mengkonfirmasi pernyataan Edram et al. (2007) bahwa produktivitas kebun swadaya lebih rendah dibandingkan kebun plasma, sehingga membuat petani swadaya mensiasatinya dengan melakukan perluasan lahan. Seluruh kebun responden yang terdata adalah tanaman menghasilkan (TM). Rata-rata sebaran usia tanaman kelapa sawit milik petani swadaya adalah 17.88 tahun, sedangkan rata-rata usia tanaman kelapa sawit petani plasma adalah 22.1 tahun. Hal ini menunjukkan bahwa responden petani swadaya memiliki kelapa sawit pada usia ekonomis ( $<25$ tahun).

Tabel 2. Karakteristik responden dan kebun sawit responden

\begin{tabular}{|l|c|c|c|c|c|c|}
\hline \multirow{2}{*}{ Karakteristik } & \multicolumn{2}{c|}{ Swadaya } & \multicolumn{2}{c|}{ Plasma } & \multirow{2}{*}{ P-value } \\
\hline Usia (tahun) & Mean & SD & Mean & SD & \\
\hline Pendidikan (tahun) & 49,66 & 10,49 & 47,71 & 10,27 & 0,072 \\
\hline Sumber penghasilan dari sawit (\%) & 8,23 & 3,98 & 8,47 & 4,32 & 0,327 \\
\hline Luas lahan (ha) & 85 & 19,57 & 82 & 18,76 & 0,114 \\
\hline Hasil panen (ton/ha) & 4,95 & 6,06 & 2,98 & 2,41 & $0,000^{*}$ \\
\hline Usia tanaman sawit (tahun) & 1,54 & 0,41 & 1,78 & 0,35 & $0,000^{*}$ \\
\hline
\end{tabular}

Sumber : Data diolah (2019); SD : Standar Deviasi; *signifikan pada $p<0.05$

\section{PERBEDAAN PERILAKU MASA LALU DAN PERILAKU YANG DIRENCANAKAN}

Analisis uji beda dilakukan terhadap perilaku masa lalu dan perilaku yang direncanakan (niat) untuk menjelaskan perubahan perilaku responden dalam menerapkan praktik-praktik keberlanjutan. Tabel 3 menunjukkan bahwa terdapat perubahan yang signifikan $(\mathrm{p} \leq 0.01)$ dan positif antara perilaku masa lalu dan perilaku yang direncanakan oleh responden swadaya pada semua praktik-praktik produksi berkelanjutan (GAP). Artinya responden swadaya memiliki kesiapan untuk berubah dalam aspek keberlanjutan perkebunan kelapa sawit. Namun, terdapat niat yang rendah pada praktik pengendalian OPT secara organik (3.81) dan mengikuti kelompok tani (3.85). Keterbatasan uang dan pengetahuan menyebabkan petani swadaya memiliki niat yang rendah untuk melakukan praktik pengendalian OPT secara organik. Petani swadaya tidak mengerti mengendalikan OPT dengan meggunakan musuh alami (parasitoid, predator dan agen hayati). Selain itu, petani swadaya juga masih bergantung pada racun kimia untuk membasmi gulma. Petani swadaya juga kurang tertarik untuk mengikuti kelompok tani karena menurutnya, mengikuti kelompok tani akan mengurangi pendapatan dari hasil kebun kelapa sawit. Hal ini dikarenakan oleh biaya pengelolaan dan perawatan kebun akan dipotong dari hasil panen yang diterima petani tiap bulannnya 
oleh KUD sebagai pemasok pupuk dan kebutuhan perawatan kebun lainnya.

Tabel 3. Uji beda perilaku masa lalu dan niat berperilaku di masa depan responden petani swadaya

\begin{tabular}{|c|c|c|c|c|c|}
\hline \multirow[t]{2}{*}{ Good Agriculture Practices } & \multicolumn{2}{|c|}{$\begin{array}{c}\text { Perilaku Masa } \\
\text { Lalu }\end{array}$} & \multicolumn{2}{|c|}{$\begin{array}{l}\text { Perilaku yang } \\
\text { direncanakan }\end{array}$} & \multirow{2}{*}{$\begin{array}{l}\text { Uji Beda } \\
\text { (p-value) }\end{array}$} \\
\hline & Mean & SD & Mean & SD & \\
\hline Membuka/membersihkan lahan tanpa bakar & 5,47 & 1,36 & 6,85 & 0,57 & $0,000^{*}$ \\
\hline Menggunakan pupuk organik & 4,36 & 2,09 & 5,42 & 1,43 & $0,000^{*}$ \\
\hline $\begin{array}{l}\text { Mengendalikan organisme pengganggu } \\
\text { tanaman (hama, penyakit dan gulma) secara } \\
\text { organik }\end{array}$ & 2,56 & 1,34 & 3,81 & 1,92 & $0,000^{*}$ \\
\hline Menggunakan bibit bersertifikat & 3,38 & 1,80 & 5,93 & 1,41 & $0,000^{*}$ \\
\hline Mengikuti kelompok tani & 1,17 & 0,94 & 3,85 & 2,17 & $0,000^{*}$ \\
\hline Menggunakan lahan bebas konflik/ sengketa & 6,45 & 1,12 & 6,83 & 0,56 & $0,000 *$ \\
\hline
\end{tabular}

Pada tabel 4 menunjukkan terdapat perubahan yang signifikan $(\mathrm{p} \leq 0.01)$ dan positif antara perilaku masa lalu dan perilaku yang direncanakan oleh responden plasma pada praktik-praktik produksi berkelanjutan (GAP). Namun, niat petani plasma pada praktik pengendalian OPT secara organik tergolong rendah (3.91). Sama seperti petani swadaya, petani plasma juga masih bergantung pada racun kimia untuk membasmi gulma. Sedangkan untuk mengendalikan hama dan penyakit pada tanaman kelapa sawit, petani plasma bergantung kepada pengelolaan dari perusahaan lewat KUD. Adanya gejala-gejala hama dan penyakit yang terlihat di kebun plasma secara langsung akan dilaporkan oleh kelompok tani ke KUD. Pada praktik mengikuti kelompok tani, terjadi perubahan niat yang cenderung menurun (rata-rata 6.90 menjadi 6.50). Hal ini terjadi karena sebagian kecil petani plasma merasakan

ketidakpuasan terhadap pola mitra yang diikutinya. Pemotongan biaya perawatan oleh KUD setiap bulannya membuat petanipetani plasma yang memiliki luas kebun kurang dari 2 hektar menerima pendapatan yang kecil. Oleh karena itu petani plasma harus meningkatkan skala usaha tani kelapa sawitnya dengan melakukan pelebaran lahan. Tidak terdapat perubahan yang signifikan ( $\mathrm{p} \geq 0.01)$ pada responden plasma dalam perencanaan perilaku menggunakan lahan bebas konflik. Hal ini terjadi karena 99 persen responden petani plasma sebelumnya telah menggunakan lahan bebas konflik dan bersertifikat BPN.

Tabel 4. Uji beda perilaku masa lalu dan niat berperilaku di masa depan responden petani plasma

\begin{tabular}{|c|c|c|c|c|c|}
\hline \multirow[t]{2}{*}{ Good Agriculture Practices } & \multicolumn{2}{|c|}{$\begin{array}{c}\text { Perilaku Masa } \\
\text { Lalu }\end{array}$} & \multicolumn{2}{|c|}{$\begin{array}{l}\text { Perilaku yang } \\
\text { direncanakan }\end{array}$} & \multirow{2}{*}{$\begin{array}{l}\text { Uji Beda } \\
\text { (p-value) }\end{array}$} \\
\hline & Mean & SD & Mean & SD & \\
\hline Membuka/membersihkan lahan tanpa bakar & 6,26 & 1,36 & 6,91 & 0,57 & $0,000 *$ \\
\hline Menggunakan pupuk organik & 3,81 & 2,09 & 5,28 & 1,43 & $0,000 *$ \\
\hline $\begin{array}{l}\text { Mengendalikan organisme pengganggu } \\
\text { tanaman (hama, penyakit dan gulma) secara } \\
\text { organik }\end{array}$ & 2,37 & 1,34 & 3,91 & 1,92 & $0,000 *$ \\
\hline
\end{tabular}




\begin{tabular}{|l|l|l|l|l|c|}
\hline Menggunakan bibit bersertifikat & 5,52 & 1,80 & 6,05 & 1,41 & $0,000^{*}$ \\
\hline Mengikuti kelompok tani & 6,90 & 0,94 & 6,50 & 2,17 & $0,003^{*, * *}$ \\
\hline Menggunakan lahan bebas konflik/sengketa & 6,90 & 1,12 & 6,95 & 0,56 & 0,078 \\
\hline
\end{tabular}

Sumber : Data diolah (2019); SD : Standar Deviasi; *signifikan pada $p \leq 0.01$; ** perubahan menurun

\section{ANALISIS PERBANDINGAN NIAT PETANI SWADAYA DAN PETANI PLASMA TERHADAP PRAKTIK PRODUKSI KELAPA SAWIT BERKELANJUTAN DENGAN SEM-PLS}

Pengujian model struktural dengan PLS dilakukan untuk mengukur pengaruh variabel independen terhadap variabel dependen. Analisis outer model menunjukkan bahwa nilai $\mathrm{R}^{2}$ untuk model struktural petani swadaya adalah 0.41 dan petani plasma 0.43 . Artinya variabel sikap, norma subjektif, persepsi dan perilaku masa lalu dapat menjelaskan dan mempengaruhi niat menerapkan GAP sebesar 41 persen pada petani swadaya dan 43 persen pada petani plasma, sisanya 59 dan 57 persen dijelaskan oleh variabel-variabel lain diluar model penelitian. Pengujian path coefficient dilakukan untuk mengukur pengaruh antar variabel konstruk. Nilai t-statistik lebih dari 1.96 dengan alpha 5 persen menunjukkan terdapat pengaruh antara variabel konstruk. Gambar 1 dan Gambar 2 menunjukkan perbedaan hasil pengujian path coefficient pada responden petani swadaya dan petani plasma.

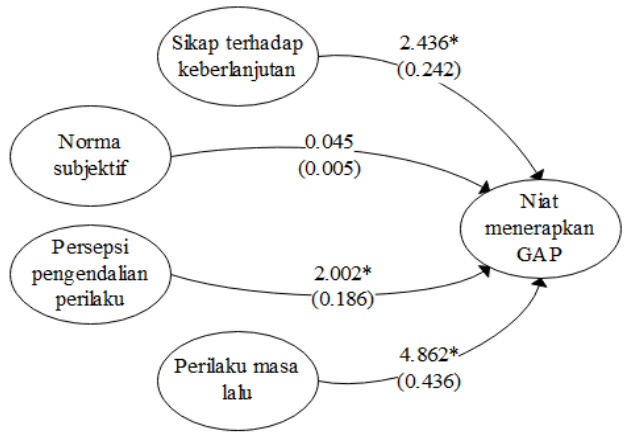

\section{Gambar 1. Hasil Path Coefficients model struktural petani pola swadaya}

Sumber : Data diolah (2019);

Keterangan: t-statistik (Original Sample)

*signifikan pada t-statistik >1.96 alpha 5\%
Hasil pengujian path coefficient pada model struktural petani swadaya dan petani plasma menunjukkan hasil yang berbeda. Petani swadaya dan petani plasma memiliki faktor-faktor yang berbeda dalam mempengaruhi niatnya melakukan praktikpraktik keberlanjutan. Gambar 1 menunjukkan bahwa pada petani swadaya, variabel sikap, persepsi dan perilaku masa lalu memiliki pengaruh yang positif dan signifikan terhadap niat petani swadaya untuk menerapkan praktik-praktik berkelanjutan. Sedangkan variabel norma subjektif bukan merupakan prediktor yang dapat mempengaruhi niat petani swadaya untuk menerapkan praktik-praktik berkelanjutan. Pada petani plasma, variabel norma subjektif, persepsi pengendalian perilaku dan perilaku masa lalu memiliki pengaruh yang positif dan signifikan terhadap niat petani plasma untuk menerapkan praktik-praktik berkelanjutan. Sedangkan variabel sikap tidak berpengaruh terhadap niat petani plasma menerapkan praktik-praktik keberlanjutan (Gambar 2).

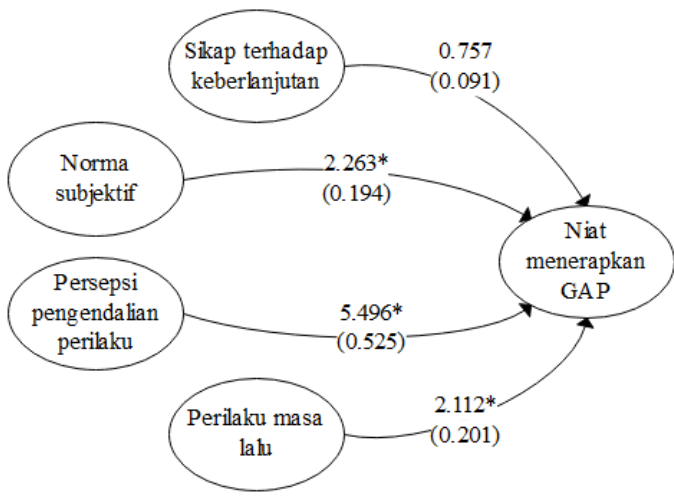

Gambar 2. Hasil Path Coefficients model struktural petani pola plasma

Sumber : Data diolah (2019);

Keterangan: t-statistik (Original Sample)

*signifikan pada t-statistik $>1.96$ alpha $5 \%$ 
Variabel sikap terhadap keberlanjutan mempengaruhi niat petani swadaya dan tidak mempengaruhi niat petani plasma. Hal ini menunjukkan bahwa dari dalam diri petani swadaya menyadari dan meyakini pentingnya menerapkan praktik-praktik keberlanjutan dalam aktivitas produksi kelapa sawit. Penelitian yang dilakukan oleh Menozzi et al. (2015), Terano et al. (2015) dan Zeweld et al. (2017) juga menunjukkan bahwa niat melakukan praktik pertanian berkelanjutan dipengaruhi oleh sikap terhadap keberlanjutan. Sedangkan pada petani plasma, tidak terdapat faktor keyakinan dari dalam diri untuk menerapkan praktik keberlanjutan. Selama ini petani plasma menyerahkan kebunnya dikelola oleh perusahaan, sehingga petani plasma menjadi kurang peduli terhadap keberlanjutan kebun kelapa sawitnya.

Petani swadaya meyakini bahwa menggunakan pupuk organik dan pengendalian OPT secara organik dapat melindungi kualitas tanah, meningkatkan kesuburan tanaman kelapa sawit dan meningkatkan produktivitas kebun. Sementara petani plasma cenderung mengandalkan pupuk kimia yang disediakan oleh koperasi, tanpa berinisiatif untuk menambah pupuk dan pengendalian OPT secara organik. Selain itu petani swadaya meyakini bahwa menggunakan bibit yang bersertifikat akan meningkatkan produktivitas kelapa sawit. Berdasarkan data penelitian, sebagian besar petani plasma telah menggunakan bibit bersertifikat. Hal ini dikarenakan oleh kerja sama yang dilakukan perusahaan inti dengan anggota plasma, sehingga perusahaan menanami kebun inti dan kebun plasma dengan benih yang bersertifikat sebagai bagian dari standar operasional perusahaan dan untuk menjaga produktivitas yang berkelanjutan. Sementara rata-rata petani swadaya hanya menggunakan bibit biasa yang diperoleh dari pihak-pihak yang tidak berlisensi, sehingga petani swadaya memiliki produktivitas lebih rendah dibandingkan dengan petani plasma.

$$
\text { Variabel norma subjektif }
$$

berpengaruh signifikan terhadap niat petani plasma dan tidak mempengaruhi niat petani swadaya. Hal ini terjadi karena petani plasma memiliki perusahaan inti sebagai pengelola dan pengambil keputusan dalam semua aktivitas produksi kelapa sawit. Pengaruh sosial tersebut mempengeruhi petani plasma dalam merencanakan perilaku (Wiratmadja 2017 dan Zeweld et al. 2017). Petani swadaya memiliki keinginan untuk melakukan praktik-praktik keberlanjutan namun pengaruh-pengaruh dari lingkungannya tidak memberikan nilai positif. Sehingga petani swadaya tidak memiliki pengaruh sosial untuk merencanakan perilakunya (Menozzi et al. 2015 dan Terano et al. 2015).

Petani swadaya dan plasma menyadari bahwa perilaku menerapkan praktik-praktik keberlanjutan memerlukan uang, waktu dan pengetahuan. Harga pupuk organik cenderung lebih mahal karena sulit didapatkan dan juga membutuhkan biaya operasional lebih banyak. Pengendalian OPT secara manual dan organik harus menghabiskan biaya besar untuk menambah tenaga kerja, menambah mesin dan alat kerja, dan bahan-bahan organik lainnya. Jika tidak, membuat pupuk organik dan pengendalian OPT secara organik dapat dilakukan sendiri, namun diperlukan pengetahuan untuk mengerjakannya. Benih kelapa sawit yang bersertifikat harganya lebih mahal dan tidak mudah untuk mendapatkan benih yang asli, maka diperlukan biaya besar dan pengetahuan untuk mendapatkannya. Semakin kuat faktor-faktor pengendali perilaku tersebut maka semakin tinggi niat petani responden untuk menerapkan praktikpraktik produksi. Niat melakukan praktik pertanian berkelanjutan dipengaruhi oleh persepsi pengendalian perilaku berkelanjutan (Terano et al. 2015, Wiratmadja 2017 dan Zeweld et al. 2017).

Perilaku masa lalu mencerminkan kebiasaan-kebiasaan yang dilakukan petani dalam aktivitas produksi kelapa sawitnya. Berdasarkan data penelitian, petani plasma dan swadaya kurang menerapkan praktik penggunaan pupuk organik dan pengendalian OPT secara organik. Petani cenderung lebih suka menggunakan pupuk kimia karena lebih mudah didapatkan serta mudah dan cepat diaplikasikan ke kebun kelapa sawit. Pengendalian OPT dilakukan 
secara instan dengan kimiawi. Secara umum keberadaan hama dan penyakit pada tanaman kelapa sawit tidak disadari oleh petani. Petani menganggap hal itu bukan suatu masalah, sehingga tidak ada penanganan lebih lanjut. Pembasmian gulma juga lebih sering dilakukan dengan menyemprotkan racun kimia. Hal inilah yang menyebabkan petani memiliki niat yang rendah untuk menggunakan pupuk dan pengendalian OPT secara organik di masa mendatang. Sebagian besar petani plasma telah menggunakan bibit kelapa sawit bersertifikat. Hal ini dikarenakan kerja sama yang dilakukan perusahaan inti dan kebun plasma, sehingga perusahaan inti menanami kebun inti dan kebun plasma dengan benih berkualitas untuk menjaga produktivitas yang berkelanjutan. Sedangkan petani swadaya kurang meyakini kualitas dari benih kelapa sawit yang ditanamnya dahulu, karena diperoleh dari pihak-pihak tidak terpercaya. Menozzi et al. (2015) yang menganalisis motivasi petani dalam menerapkan praktik-praktik produksi berkelanjutan, yaitu perilaku masa lalu mempengaruhi niat petani untuk menerapkan sebuah perilaku. Dharmmesta (2000) juga menyatakan ketika seseorang tidak mampu menentukan sebuah sikap, maka kebiasaan-kebiasaan di masa lalu akan dilakukan di masa yang akan datang.

\section{IMPLIKASI MANAJERIAL}

Perbedaan pola swadaya dan plasma telah mempengaruhi niat petani kelapa sawit di Kabupaten Kampar terhadap praktikpraktik produksi kelapa sawit berkelanjutan. Meningkatkan sikap terhadap keberlajutan dan persepsi pengendalian perilaku dapat meningkatkan niat petani untuk menerapkan praktik-praktik berkelanjutan. Petani mengakui bahwa menerapkan praktikpraktik produksi berkelanjutan memerlukan biaya yang lebih banyak, waktu yang lebih lama, dan pengetahuan yang lebih tinggi. Untuk mengatasi keterbatasan biaya, petani sebaiknya mencari sumber penghasilan lain untuk mendukung biaya perawatan kelapa sawit secara berkelanjutan. Upaya peningkatan penghasilan ini dapat dilakukan dengan memanfaatkan kebun kelapa sawit sebagai tempat peternakan, hal ini sekaligus mendukung pengadaan pupuk kandang dan minimalisasi gulma. Sedangkan keterbatasan waktu dapat diatasi jika memiliki cukup uang untuk menggunakan bantuan teknologi maupun penambahan tenaga kerja. Sementara keterbatasan pengetahuan dapat didukung dengan adanya pendidikan informal seperti program penyuluhan dan sosialisasi lewat media massa (televisi, sosial media, koran, dan lain-lain), hal ini juga akan meningkatkan kesadaran dan sikap petani terhadap keberlanjutan.

Peningkatan perilaku keberlanjutan pada petani swadaya membutuhkan dukungan dari berbagai pihak, seperti perusahaan kelapa sawit, program penyuluhan dan pemerintah. Perusahaan kelapa sawit besar sebaiknya menjadi normative referent/role model bagi petani swadaya dalam penerapan praktik-praktik keberlanjutan di kebun kelapa sawit. Dengan melihat perusahaan besar melakukan praktik-praktik berkelanjutan, maka petani swadaya akan merespon perilaku tersebut sebagai sesuatu yang baik untuk dilakukan Perilaku yang baik atau buruk di lingkungan sekitar akan menjadi stimulus bagi seseorang untuk menentukan sebuah perilaku. Sebaliknya, petani harus meningkatkan sikap dan persepsinya terhadap praktik-praktik keberlanjutan yang dilakukan oleh orangorang di sekitarnya. Pemerintah dapat memberikan dukungan terhadap petani swadaya, meningkatkan harga sawit, memperkuat industri hilir, program subsidi peremajaan sawit rakyat dalam rangka peningkatan produktivitas perkebunan rakyat, menyempurnakan sistem kelembagaan usaha tani melalui pembentukan kelompok tani dan KUD. Program penyuluhan dapat mendidik dan menumbuhkan kesadaran petani kelapa sawit akan pentingnya menerapkan praktikpraktik keberlanjutan. Program penyuluhan 
dari Badan Penyuluh Perkebunan (BPP) setiap daerah kecamatan, selain melayani kelompok tani dan perusahaan besar juga diharapkan dapat melayani petani swadaya. Program pendidikan informal tersebut sangat dibutuhkan swadaya untuk meningkatkan kesadaran dan kemampuannya melakukan praktik-praktik keberlanjutan, seperti pembuatan pupuk organik dan program pendampingan petani dalam pengendalian OPT secara terpadu.

\section{KESIMPULAN DAN SARAN}

\section{KESIMPULAN}

Perbedaan pola swadaya dan plasma membedakan faktor-faktor pembentuk niat petani kelapa sawit di Kabupaten Kampar. Variabel sikap, persepsi pengendalian perilaku dan perilaku masa lalu memiliki pengaruh signifikan terhadap niat petani swadaya untuk menerapkan praktik-praktik keberlanjutan pada kebun kelapa sawitnya. Sedangkan pada petani plasma, variabel sikap tidak memiliki pengaruh untuk membentuk niat terhadap keberlanjutan. Namun, petani plasma memiliki norma subjektif, persepsi pengendalian perilaku dan perilaku masa lalu yang positif untuk merencanakan perilaku keberlanjutan di kemudian hari.

Dengan meningkatkan nilai norma subjektif pada petani swadaya, yaitu pengaruh sosial dari lingkungan sekitar (petani lain, perusahaan besar, program penyuluhan), maka petani swadaya dapat meningkatkan niatnya menerapkan praktikraktik produksi kelapa sawit berkelanjutan. Meningkatkan nilai sikap petani plasma terhadap keberlanjutan dengan pemahaman akan manfaat-manfaat yang dapat diperoleh dari praktik-praktik keberlanjutan, dapat meningkatkan niat petani plasma untuk menerapkan praktik-raktik produksi kelapa sawit berkelanjutan. Sehingga petani plasma dan petani swadaya bersama-sama siap menuju produksi kelapa sawit berkelanjutan.

\section{SARAN}

Penerapan praktik pertanian berkelanjutan pada perkebunan kelapa sawit rakyat dapat ditingkatkan dengan melakukan kerja sama dengan berbagai pihak seperti perusahaan besar negara, perusahaan besar swasta dan program penyuluhan, serta dukungan dari pemerintah. Perusahaan kelapa sawit dapat menjadi normatif referent dalam menerapkan praktik-praktik keberlanjutan. Pemerintah dapat memberikan dukungan terhadap petani rakyat khususnya petani swadaya, meningkatkan harga, memperkuat industri hilir, program subsidi peremajaan sawit rakyat dalam rangka peningkatan produktivitas perkebunan rakyat, menyempurnakan sistem kelembagaan usaha tani melalui pembentukan kelompok tani dan KUD. Program penyuluhan dapat mendidik dan menumbuhkan kesadaran petani kelapa sawit akan pentingnya menerapkan praktik-praktik keberlanjutan. Program pendidikan informal seperti penyuluhan sangat dibutuhkan petani rakyat khususnya petani swadaya untuk meningkatkan kesadaran dan kemampuannya melakukan praktik-praktik keberlanjutan, pembuatan pupuk organik, dan program pendampingan petani dalam pengendalian OPT secara terpadu.

Bagi peneliti selanjutnya, diharapkan dapat mengembangkan model dengan menambah referensi yang dapat mendukung penelitian ini sehingga dapat secara lebih detail menjelaskan proses pembentukan perilaku keberlanjutan petani. Peneliti selanjutnya juga diharapkan dapat melanjutkan penelitian ini dengan menganalisis sejauh mana peningkatan perilaku responden di periode berikutnya atau setelah re-planting.

\section{DAFTAR PUSTAKA}

Ajzen I, Fishbein M. 2005. The influence of attitudes on behavior. In Albarracin, D, Johnson, BT, Zanna MP. (Eds), The 
handbook of attitudes, Lawrence Erlbaum Associates.

Andoko, Agus, Widodoro. 2013. Berkebun Kelapa Sawit si Emas Cair. Jakarta (ID): PT Agro Media Pustaka.

Aikanathan S, Chenayah S, Sasekumar A. 2011. Sustainable Agriculture: A Case Study On The Palm Oil Industry. Malaysia Journal Of Science. 30(1), 66-75.

[BPS] Badan Pusat Statistik. 2015. Luas dan Produksi Perkebunan Rakyat Komoditi Sawit menurut Kecamatan Tahun 2013. [Diakses 2018 September 20]; Tersedia pada: http://kamparkab.bps.go.id/ statistictable/2015/05/17/13/luas-danproduksi-perkebunan-rakyat-komoditikelapa-sawit-menurut-kecamatantahun-2013.

[DITJENBUN] Direktorat Jenderal Perkebunan. 2017. Statistik Perkebunan Indonesia 2015-2017: Kelapa Sawit. Kementerian Pertanian (ID). [Diakses 2018 Agustus 12]; Tersedia pada: http:/ / ditjenbun.pertanian.go.id/tinym cpuk/gambar/file/statistik/2017/Kelap a-Sawit-2015-2017.

Dharmmesta BS. 2000. Perilaku Mencoba Beli: Sebuah Kajian Analitis Model Bagozzi Warshaw untuk Panduan Peneliti. Jurnal Ekonomi Dan Bisnis Indonesia. 12(3): 1- 27

[GAPKI] Gabungan Pengusaha Kelapa Sawit Indonesia. 2017. Sawit dan Kebijakan Industrialisasi menuju 2050. [Diakses 2018 September 10]; Tersedia pada: https://gapki.id/news/3209/sawitdan-kebijakan-industrialisasi-sawitmenuju-2050.

Hadi S, Rifai A, Qomar N. 2009. Industri Kelapa Sawit Rakyat di Riau Membangun Kemandirian Petani. Pekanbaru (ID): UNRI Press.

Hagger MN, Chatzisarantis S, Biddle. 2002, A Meta-Analytic Review of the Theories of Reasoned Action and Planned Behavior in Physical Activity: Predictive Validity and the Contribution of Additional Variables, Journal of Sport \& Exercise Psychology. 24, 3-32.

Hansson H, Ferguson R, Olofsson C, Rantamäki-Lahtinen L. 2013. Farmers' motives for diversifying their farm business-The influence of family. Journal of Rural Studies. 32, 240-250.

Menozzi D, Fioravanzi M, Donati M. 2015. Farmer's motivation to adopt sustainable agricultural practices. Biobased and Applied Economics. 4(2). 125147, doi: 10.13128/BAE-14776.

Terano R, Mohamed Z, Shamsudin MN, Latif IA. 2015. Factors influencing intention to adopt sustainable agriculture practices among paddy farmers in Kada, Malaysia. Asian Journal Agriculture Research. 9(5), 268-275. doi: 10.3923/ajar.2015. 268.275

Wiratmadja I. 2017. Model Penerimaan Petani terhadap Teknologi Sistem Pertanian Organik di Kabupaten Tasikmalaya. Jurnal Manajemen Teknologi. 16(1), 81-91. doi:10.12695/jmt.2017.16.1.6.

Yazdanpanah M, Hayati D, HochrainerStigler S, Zamani GH. 2014. Understanding farmers' intention and behavior regarding water conservation in the Middle-East and North Africa: A case study in Iran. Journal of Environmental Management. 135, 63-72.

Zeweld W, van Huylenbroeck G, Tesfay G, Speelman S. 2017. Smallholder farmers' behavioral intentions towards sustainable agricultural practices. Journal Environment Management. 187, 71-81 